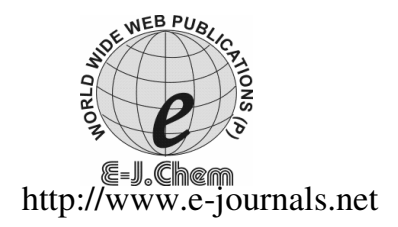

ISSN: 0973-4945; CODEN ECJHAO

E-Journal of Chemistry 2010, 7(1), 246-252

\title{
Stability Indicating RP-HPLC Method for Determination of Valsartan in Pure and Pharmaceutical Formulation
}

\author{
S. K. PATRO ${ }^{\S *}$, S. K. KANUNGO ${ }^{\S}$, \\ V. J. PATRO\# and N. S. K. CHOUDHURY \\ ${ }^{\S}$ Department of Pharmaceutical Analysis \& Quality Assurance, \\ Institute of Pharmacy and Technology, Salipur, Cuttack, Orissa-754202, India. \\ ${ }^{\#}$ College of Pharmaceutical Sciences, Mohuda, Berhampur, Ganjam, Orissa, India. \\ Department of Pharmacy, S. C.B. Medical College, Cuttack, Orissa, India. \\ skpatro69@gmail.com
}

Received 8 July 2009; Accepted 5 September 2009

\begin{abstract}
A simple, rapid and accurate and stability indicating RP-HPLC method was developed for the determination of valsartan in pure and tablet forms. The method showed a linear response for concentrations in the range of 50-175 $\mu \mathrm{g} / \mathrm{mL}$ using $0.01 \mathrm{M} \mathrm{NH}_{4} \mathrm{H}_{2} \mathrm{PO}_{4}$ (pH 3.5) buffer: methanol [50:50] as the mobile phase with detection at $210 \mathrm{~nm}$ and a flow rate of $1 \mathrm{~mL} / \mathrm{min}$ and retention time $11.041 \mathrm{~min}$. The method was statistically validated for accuracy, precision, linearity, ruggedness, robustness, forced degradation, solution stability and selectivity. Quantitative and recovery studies of the dosage form were also carried out and analyzed; the \% RSD from recovery studies was found to be less than 1 . Due to simplicity, rapidity and accuracy of the method, we believe that the method will be useful for routine quality control analysis.
\end{abstract}

Keywords: Valsartan, RP-HPLC, Degradation studies.

\section{Introduction}

Stability indicating methods have become an important aspect of any analytical method validation and a part of US FDA requirements ${ }^{1}$. Chemically, valsartan is designated as $N$-(1-oxopentyl)- $N$ - $\left\{[2\right.$ '-(1H-tetrazol-5-yl)[1,1'-biphenyl]-4-yl]methyl $\}-L$-valine ${ }^{2}$. Valsartan is a new antihypertensive drug, which is non-peptide potent highly selective, orally active antagonist at the angiotensin II $\mathrm{AT}_{1}$-receptors ${ }^{3-5}$. Very few methods appeared in the literature in the spectrophotometric determination of valsartan ${ }^{6,7}$. Therefore, we have made an attempt to develop a new, simple, accurate stability indicating RP-HPLC method for the determination of valsartan in pure and tablet forms. The proposed method was validated as per ICH guidelines $\mathrm{Q} 2 \mathrm{~A}^{8}$. 


\section{Experimental}

All analytical works were performed on Shimadzu HPLC LC 2010 CHT series equipped with quaternary constant flow pump, auto injector, SPDM 10 A VP Shimadzu Photo Diode array detector, LC Solution Version 1.22 SP1 software, Phenomenex Gemini C18 column (4.6 $\mathrm{mm} \times 25 \mathrm{~cm}, 5 \mu \mathrm{m}$ particle size) as stationary phase, a calibrated electronic single pan balance Sartorius CP 225 D, pH Meter of LABINDIA, Enertech Fast Clean Ultrasonic cleaner were also used during the analysis. Analytically pure valsartan has been obtained as a gift sample from M/s Torrent Pharmaceutical Ltd., (Ahmedabad, India). Tablet (Diovan ${ }^{\mathrm{R}}$ ) was purchased from the local market. All chemicals and reagents used were of AR/HPLC grade.

\section{Preparation of mobile phase and standard stock solution}

The mobile phase was prepared by mixing $500 \mathrm{~mL}$ of $0.01 \mathrm{M}$ ammonium dihydrogen orthophosphate $\left[\mathrm{NH}_{4} \mathrm{H}_{2} \mathrm{PO}_{4}\right]$ (pH adjusted to 3.5 with formic acid) buffer with $500 \mathrm{~mL}$ of methanol. The mobile phase was sonicated 10 minutes and then it was filtered through a $0.45 \mu$ membrane filter paper. An accurately weighed quantity of $25 \mathrm{mg}$ was transferred to $100 \mathrm{~mL}$ volumetric flask, which was then dissolved and made up to volume with mobile phase to give $250 \mu \mathrm{g} / \mathrm{mL}$.

\section{Optimised chromatographic conditions}

RP- HPLC analysis was performed by isocratic elution with flow rate of $1 \mathrm{~mL} / \mathrm{min}$. The mobile phase containing $0.01 \mathrm{M}$ ammonium dihydrogen orthophosphate ( $\mathrm{pH}$ adjusted to 3.5 with Formic acid) buffer and methanol in the ratio of 50:50 (v/v) to obtain well resolved peak of valsartan $\left(\mathrm{R}_{\mathrm{t}}=11.041 \mathrm{~min}\right)$ as shown in Figure 1. Wavelength of maximum absorption was selected by Photo diode Array detector. The drug shows reasonably good response at $210 \mathrm{~nm}$.

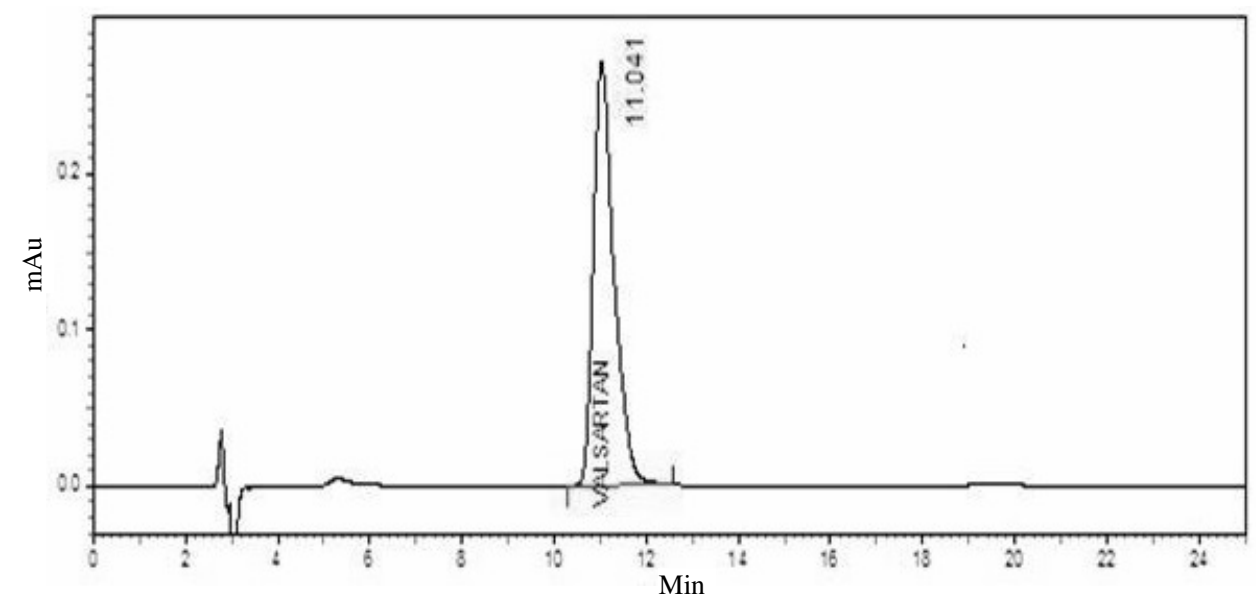

Figure 1. A typical chromatogram of standard valsartan.

\section{Calibration curve for valsartan}

Appropriate aliquots of standard stock solution were taken in different $10 \mathrm{~mL}$ volumetric flasks and diluted up to the mark with mobile phase to obtain final concentrations of 50,75, $100,125,150$ and $175 \mu \mathrm{g} / \mathrm{mL}$ of valsartan respectively. The solutions were injected using a $20 \mu \mathrm{L}$ fixed loop system and chromatograms were recorded. Calibration curve was drawn by plotting average peak area versus concentrations as shown in the Figure 2. The linearity table of valsartan is shown in Table 1. 


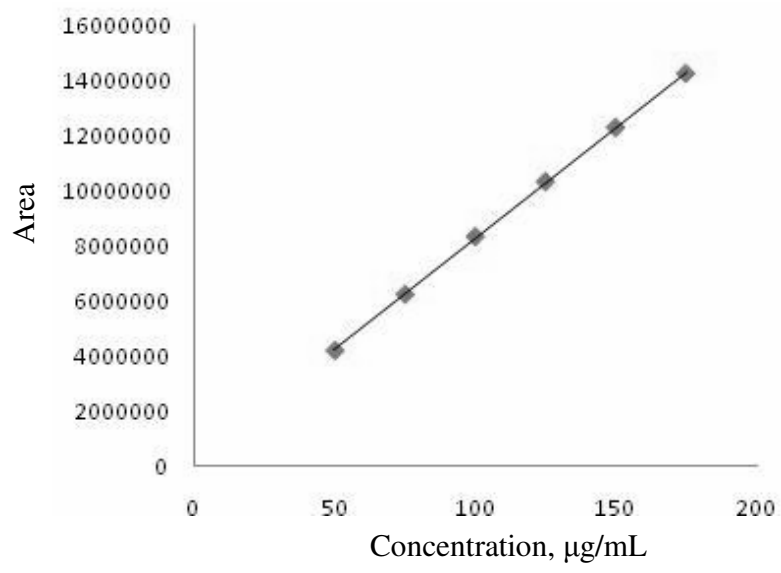

Figure 2. Calibration curve of valsartan.

Table 1. Linearity of valsartan.

\begin{tabular}{cc}
\hline Concentration, $\mu \mathrm{g} / \mathrm{mL}$ & Area \\
\hline 50 & 4198917 \\
75 & 6239634 \\
100 & 8337972 \\
125 & 10336689 \\
150 & 12302522 \\
175 & 14268455 \\
\hline
\end{tabular}

\section{Analysis of the marketed formulations}

Twenty tablets were weighed accurately and crushed to form fine powder. Accurately weighed quantity of powder equivalent to $80 \mathrm{mg}$ of valsartan was dissolved in $100 \mathrm{~mL}$ of volumetric flask with the mobile phase. The flask was sonicated for $20 \mathrm{~min}$ and then the solution was filtered using Whatmann filter paper No. 1. Appropriate volumes of the aliquot were transferred into five different $20 \mathrm{~mL}$ volumetric flasks and the volume was made up to the mark with mobile phase to obtain $100 \mu \mathrm{g} / \mathrm{mL}$ of valsartan. The solution was sonicated for $10 \mathrm{~min}$ and injected under above chromatographic conditions and peak areas were measured. The results are shown in the Table 2.

Table 2. Analysis of commercial Tablet $\left(\operatorname{Diovan}^{\mathrm{R}}\right)(* \mathrm{n}=5)$.

\begin{tabular}{cccccc}
\hline Analyte & $\begin{array}{c}\text { Label claim } \\
\mathrm{mg} / \text { tablet }\end{array}$ & $\begin{array}{c}\text { Amount Found } \\
\mathrm{mg} / \mathrm{tablet}\end{array}$ & C.I. & $\% \mathrm{RSD}$ & $\mathrm{t}$ \\
\hline Valsartan & 80 & 79.8625 & $99.8281 \pm 1.1302$ & 0.7114 & 0.4840 \\
\hline
\end{tabular}

* Mean of 5 determinations

\section{Validation of the method}

The developed method was validated in terms of linearity, accuracy, specificity, limit of detection and limit of quantitation, intra-day and inter-day precision and repeatability of measurement.

\section{Linearity}

The linearity range was found $50-175 \mu \mathrm{g} / \mathrm{mL}$. The regression equation for valsartan was found to be $Y=81,549.4425 x+91,187.9057$ and correlation coefficient $\left(r^{2}=0.9998\right)$. 


\section{Precision}

Intra-day and inter-day precision of the assay samples containing valsartan $(75,100,125,150 \mu \mathrm{g} / \mathrm{mL})$ were analyzed five times in the same day (intraday) and for three consecutive days by different analysts. Precision was calculated as intra and inter-day coefficient of variation [\% C.V. = (S. D. /mean) $\times 100]$ as shown in the Table 3.

Table 3. Precision data of the proposed method $(* n=5)$.

\begin{tabular}{ccccccc}
\hline \multirow{3}{*}{ Analyte } & \multicolumn{3}{c}{ Intraday measurement } & \multicolumn{3}{c}{ Inter-day measurement } \\
\cline { 2 - 7 } & $\begin{array}{c}\text { Conc. } \\
\mu \mathrm{g} / \mathrm{mL}\end{array}$ & \multirow{2}{*}{ Area } & \%C.V. & $\begin{array}{c}\text { Conc. } \\
\mu \mathrm{g} / \mathrm{mL}\end{array}$ & Area & \multirow{2}{*}{$\%$ C.V. } \\
\hline \multirow{3}{*}{ Valsartan } & 75 & 6244337.09 & 0.081 & 75 & 6225047.16 & 0.213 \\
& 100 & 8334707.85 & 0.064 & 100 & 8313498.93 & 0.317 \\
& 125 & 10340506.14 & 0.062 & 125 & 10331080.65 & 0.137 \\
& 150 & 12289328.99 & 0.090 & 150 & 12266412.46 & 0.317 \\
\hline
\end{tabular}

* Mean of 5 determinations

\section{Accuracy}

It was found out by recovery study using standard addition method. Known amounts of standard valsartan was added to pre-analyzed samples at a level from 50\% up to $100 \%$ and then subjected to the proposed HPLC method ${ }^{9}$. Results of recovery studies are shown in Table 4.

Table 4. Recovery studies of valsartan.

\begin{tabular}{cccccccc}
\hline Analyte & $\begin{array}{c}\text { Formulation } \\
\mu \mathrm{g} / \mathrm{mL}\end{array}$ & $\begin{array}{c}\text { Amount of } \\
\text { Standard drug } \\
\text { added, } \mu \mathrm{g} / \mathrm{mL}\end{array}$ & $\begin{array}{c}\text { Amount } \\
\text { recovered, } \\
\mu \mathrm{g} / \mathrm{mL}\end{array}$ & C.I. & $\begin{array}{c}\% \mathrm{RS} \\
\mathrm{D}\end{array}$ & $\mathrm{SE}$ & $\mathrm{t}$ \\
\hline Valsartan & 75 & 37.5 & 37.485 & $99.96 \pm 1.089$ & 0.685 & 0.342 & 0.116 \\
& 75 & 56.25 & 56.045 & $99.63 \pm 0.624$ & 0.393 & 0.196 & 1.858 \\
& 75 & 75 & 75.0275 & $100.03 \pm 0.550$ & 0.345 & 0.172 & 0.212 \\
\hline
\end{tabular}

SD: Standard deviation, SE: standard error, C.I.: Confidence Interval within which true value may be found at $95 \%$ confidence level $=R \pm t s / \sqrt{n}$, R: Mean percent result of analysis of Recovery study $(n=4)$. Theoretical ' $t$ ' values at $95 \%$ confidence level for $n-1$ degrees of freedom $t(0.05,3)=3.182$.

\section{Robustness}

By introducing small but deliberate changes in the mobile phase $\mathrm{pH}( \pm 0.1)$, mobile phase composition $( \pm 2 \%)$, detection wavelength $( \pm 5.0 \mathrm{~nm})$, flow rate $( \pm 10.0 \%$ of absolute value) robustness of the described method were studied. The robustness of the method was assessed for 3 different amounts of the calibration plot $(75,100,125 \mu \mathrm{g} / \mathrm{mL})$.

\section{Sensitivity}

The sensitivity of the method was determined with respect to LOD and LOQ. The LOD and LOQ were separately determined based on the standard calibration curve. LOD $=(3.3 \times$ S.D $/ \mathrm{S}$ and $\mathrm{LOQ}=10 \times \mathrm{S} . \mathrm{D} / \mathrm{S}$, where, S.D is the standard deviation of the $y$-intercepts of regression line and $\mathrm{S}$ is the average slope of the calibration curve.

\section{Forced degradation studies}

Forced degradation studies were performed to evaluate the stability indicating properties and specificity of the method. Intentional degradation was carried out by exposing the $20 \mathrm{mg}$ 
of samples in three different $20 \mathrm{~mL}$ volumetric flasks containing acid $\left(0.1 \mathrm{~N} \mathrm{HCl}\right.$, at $\left.40{ }^{\circ} \mathrm{C}\right)$, basic $\left(0.1 \mathrm{~N} \mathrm{NaOH}\right.$, at $\left.40{ }^{\circ} \mathrm{C}\right)$ and hydrogen peroxide $\left(3 \% \mathrm{H}_{2} \mathrm{O}_{2}\right)$ and kept for 2 hours. Then aliquot $2 \mathrm{~mL}$ was transferred into another three $20 \mathrm{~mL}$ volumetric flasks and made up to the mark with mobile phase in order to get $0.1 \mathrm{mg} / \mathrm{mL}$. All these three volumetric flasks were kept in the darkness to exclude the possible degradation effect of light. $20 \mu \mathrm{L}$ of sample solutions were injected and analyzed against control samples (lacking of degradation treatment). The results of forced degradation studies are shown in Table 5.

Table 5. Forced degradation study of valsartan.

\begin{tabular}{cccc}
\hline Agent & Exposure time, $h$ & Condition & Assay \% \\
\hline $0.1 \mathrm{~N} \mathrm{HCl}^{*}$ & 2 & Heat & 93.55 \\
$0.1 \mathrm{~N} \mathrm{NaOH}^{*}$ & 2 & Heat & 101.402 \\
$3 \% \mathrm{H}_{2} \mathrm{O}_{2}$ & 2 & Normal & 92.42 \\
\hline \multicolumn{4}{c}{${ }^{* \text { Heat at }} 40^{\circ} \mathrm{C}$}
\end{tabular}

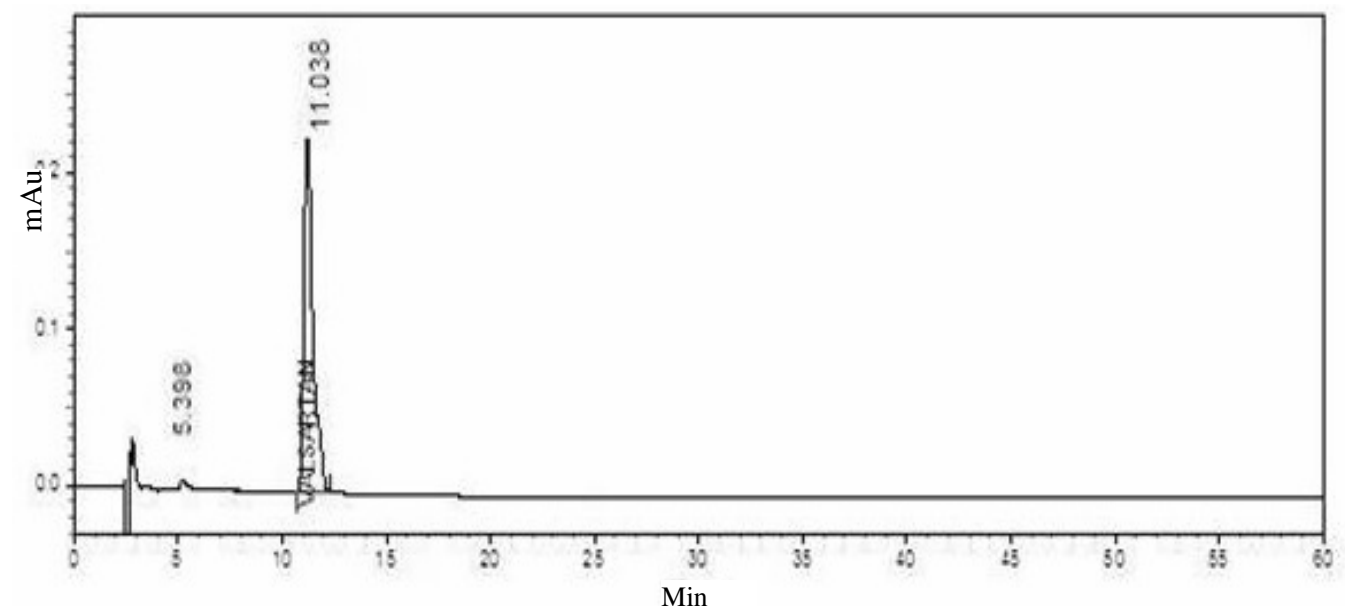

Figure 3. Acid degradation of valsartan.

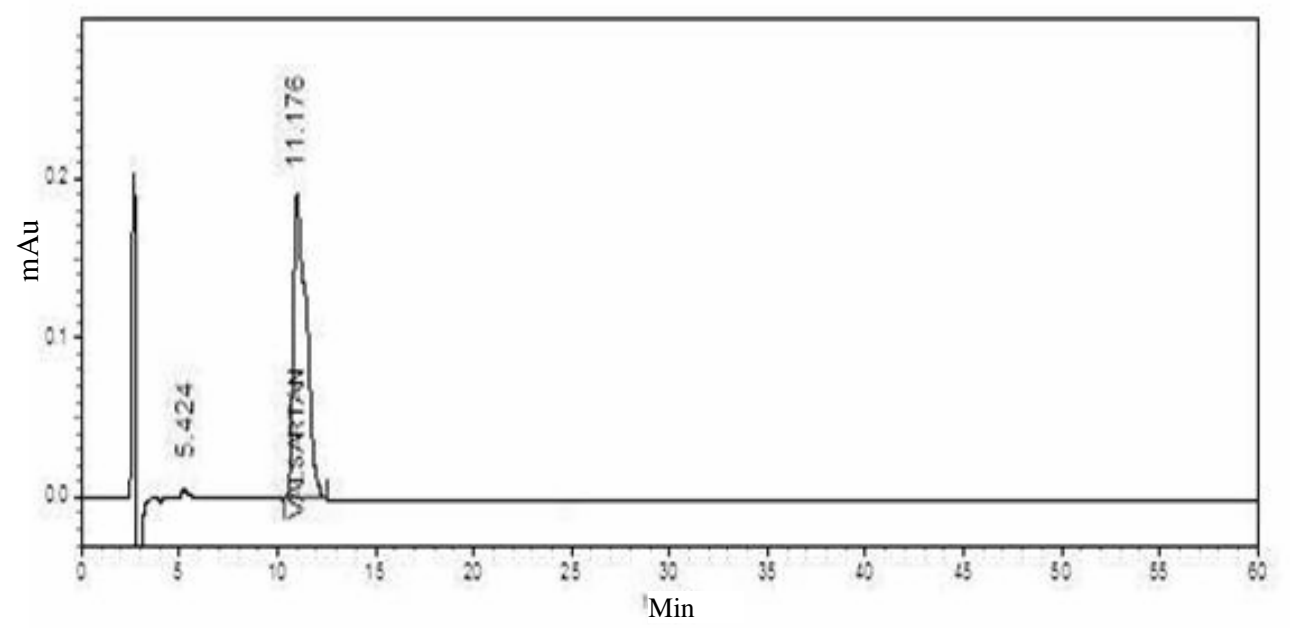

Figure 4. Basic degradation of valsartan. 


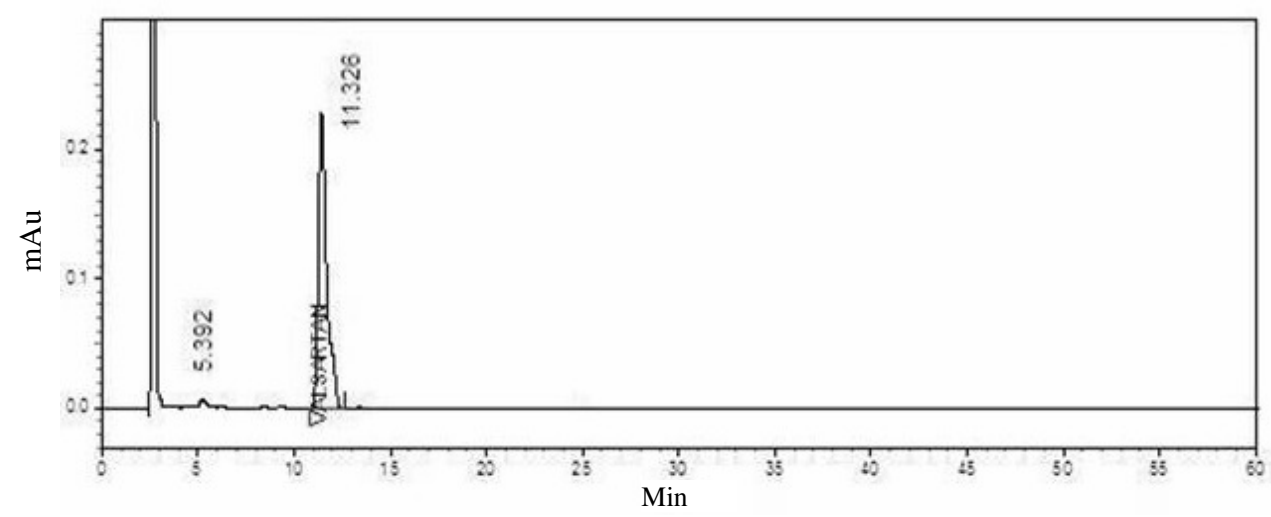

Figure 5. Oxidative degradation of valsartan.

\section{Results and Discussion}

A mobile phase consisting of buffer ( $\mathrm{pH}$ 3.5) and methanol in the ratios of 50:50 gave a well resolved, sharp peak for valsartan with a retention time of $11.041 \mathrm{~min}$. The flow rate was $1 \mathrm{~mL} / \mathrm{min}$ and effluent was monitored at $210 \mathrm{~nm}$ and a Phenomenex Gemni C18 column and $25{ }^{\circ} \mathrm{C}$ temperatures for the HPLC system and were found to be the best for the analysis. System suitability was performed by injecting five replicate injections of working standard solution $(100 \mu \mathrm{g} / \mathrm{mL})$. The system suitability results are shown in Table 6 .

Table 6. System suitability.

\begin{tabular}{cc}
\hline Parameter & Results \\
\hline Retention time, min & 11.041 \\
Theoretical plate & 3273.605 \\
Capacity factor & 1102.75 \\
Asymetric factor & 1.405 \\
Repeatability & $0.071(\%$ RSD $)$ \\
\hline
\end{tabular}

The results of specificity studies indicated no interference from excipients, impurities and degraded products due to various stress conditions and assured that the peak response was due to a single component only. The chromatogram of samples degraded with acid, base and hydrogen peroxide showed one small peak having retention time 5.398, 5.424 and 5.392 mins and well resolved from the drug peak, the chromatograms are shown in Figures 3, 4 and 5. The \% RSD was less than 1 in intraday, inter-day precision and in each parameter of robustness. So the proposed method is more precise and robust. The lower limit of Detection and the limit of quantitation were found to be 0.0388 and $0.1176 \mu \mathrm{g} / \mathrm{mL}$ respectively.

\section{Conclusion}

The modalities adopted in experimentation were successfully validated as per analytical procedures laid down in routine. The proposed method was validated by preliminary analysis of standard sample and by recovery studies. The percentage of average recoveries was obtained in the range of 98.89 to 100.587 . The results of analysis of average recoveries obtained in each instance were compared with the theoretical value of 100 percent by means 
of Student's t test. As the calculated ' $t$ ' values are less than theoretical' values (Table 4), it is concluded that the results of recoveries obtained in agreement with 100 percent for each analyte are accurate. The absence of additional peaks in the chromatogram indicates noninterference of the common excipients used in the tablets. This demonstrates that the developed HPLC method is new, simple, linear, accurate, sensitive and reproducible, and stability indicating assay. Thus, the developed method can be easily used for the routine quality control of bulk and tablet form.

\section{Acknowledgement}

The authors are thankful to the Director of Startech Pvt Ltd, Hyderabad for providing the necessary facilities to carry out this work.

\section{References}

1. Rockville M D, United States Pharmacopoeia; $25^{\text {th }}$ Edn., United States Pharmacopoeial Convention Inc, 2002, 2150.

2. Budavri S, The Merck Index; $12^{\text {th }}$ Edn; Merk \& Co, Inc., Whitehouse Station, NJ, 1996, 1691.

3. Crisscione L, Gasparo M D, Buhlamayer P, Whitebread S, Ramjoune and Wood J Br J Pharmacol., 1993, 110, 761-771.

4. Criscione L, Bradlely W A, Buhlmayer P, Whitebread S, Glazer R P, Lloyd P, Mueller M and Gasparo M D, Drug Rev., 1995, 13, 230- 250.

5. Thurmann P V, Expert Opin Pharmacother., 2000, 1, 337-350.

6. Satana E, Altinay S, Goeger S A and Ozkan Z Sanmurk, J Pharm Biomed Anal., 2001, 25, 1009-1013.

7. Tatar S and Saglik S, J Pharm Biomed Anal., 2002, 30, 371-375.

8. Carstensen J T and Rhodes C T, Drug Stability; $2^{\text {nd }}$ Edn., Marcel Dekker, New York, $2008,358$.

9. $\quad$ Snyder L R, Kirkland J J and Glajch J L, Practical HPLC method development, $2^{\text {nd }}$ Edn., Wiley-interscience Publication, John Wiley \& Sons, Inc, 1997, 709. 


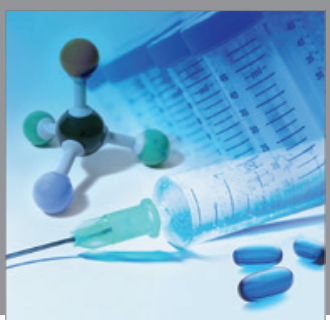

International Journal of

Medicinal Chemistry

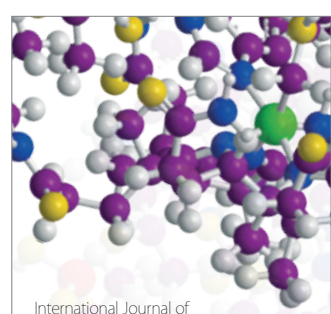

Carbohydrate Chemistry

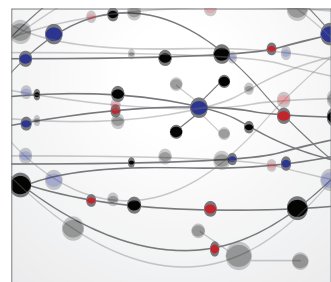

The Scientific World Journal
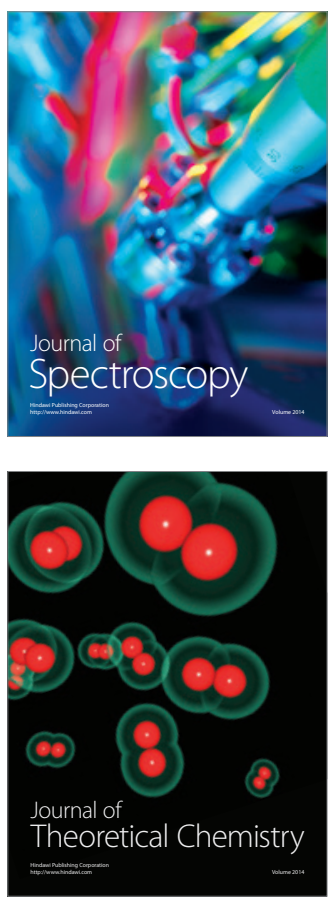
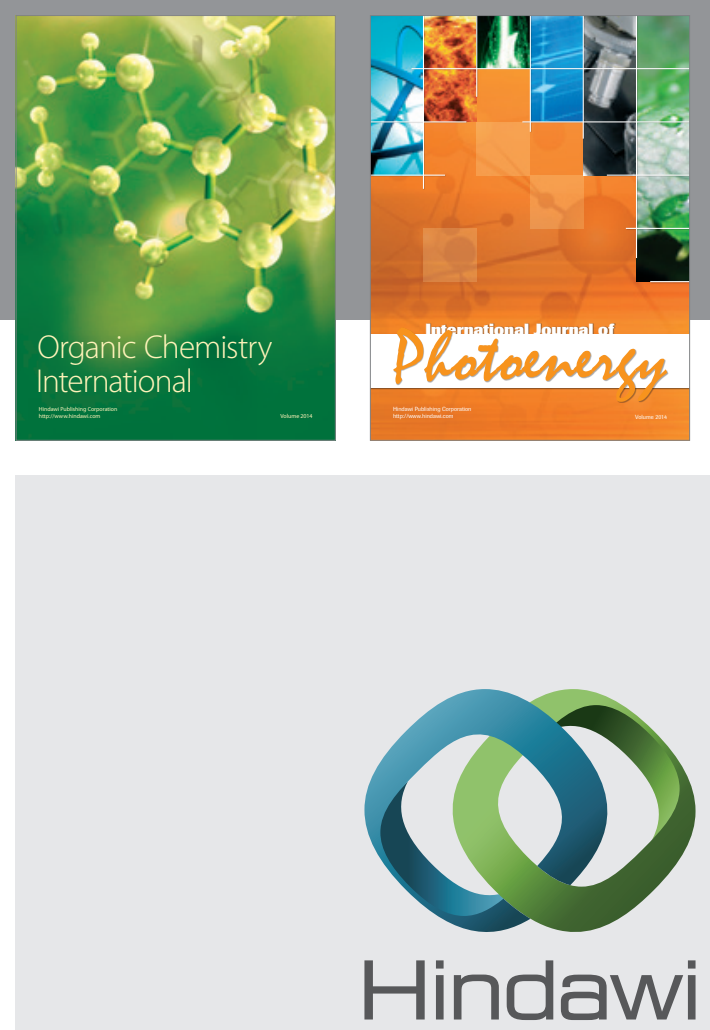

Submit your manuscripts at

http://www.hindawi.com
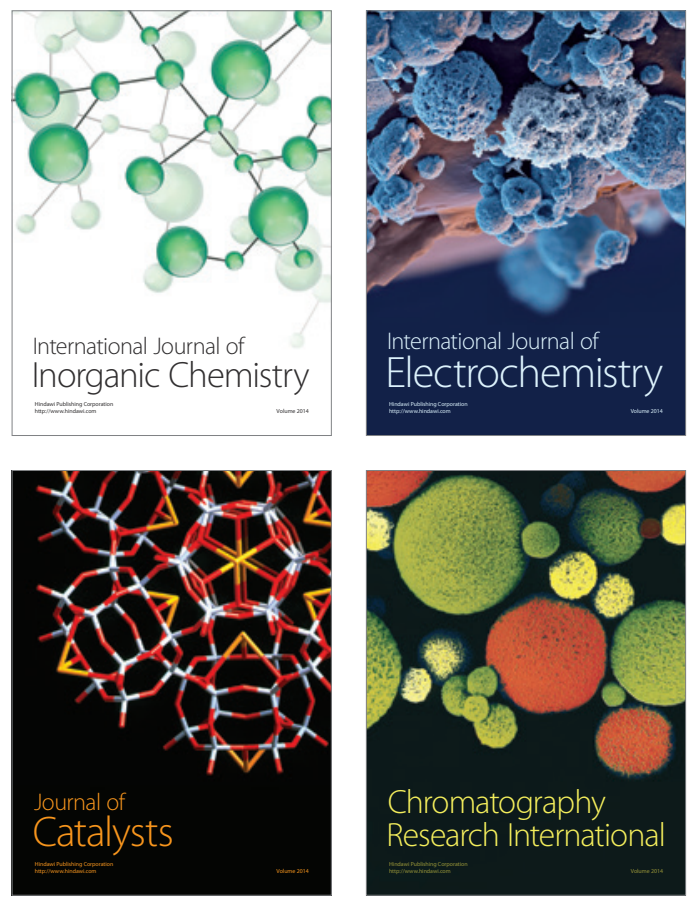
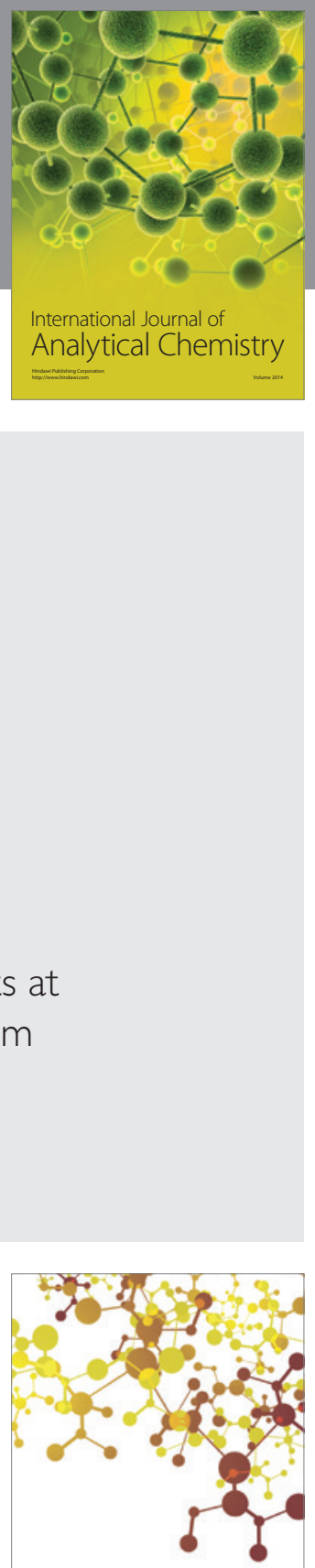

Journal of

Applied Chemistry
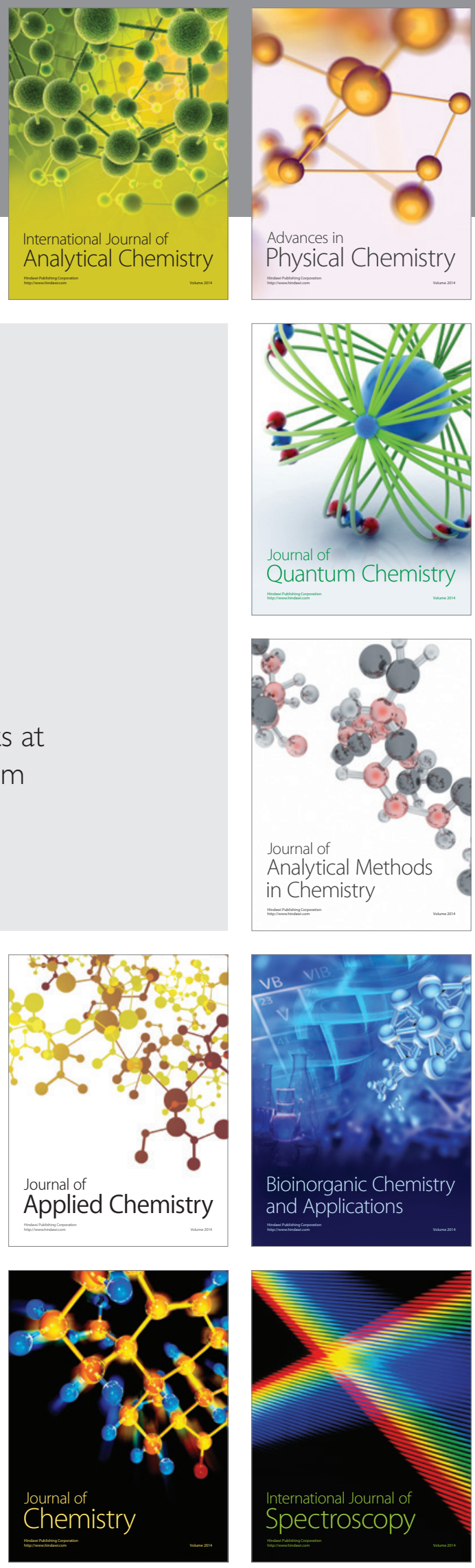